\title{
Encounters with Winston Churchill
}

\author{
W RUSSELL BRAIN
}

\section{Introduction \\ Michael C Brain*}

W Russell Brain (1895-1966) was two weeks short of his fifty-fourth birthday when he first saw Winston Churchill in consultation at the request of Lord Moran ${ }^{1}$ on 5 October 1949. Russell Brain was a consultant physician at the (then) London Hospital and the Maida Vale Hospital For Nervous Diseases. He earned his living primarily from his private practice in Harley Street as a consultant neurologist, and, latterly and more significantly, as the author of Diseases of the nervous system, Clinical neurology, and other medical and non-medical books.

In the 1950s and 1960s neurological diagnosis was based on the interpretation of the clinical history and of the clinical signs: altered mentation, perception, speech, movement and sensation. This included testing the visual fields, examining the optic fundi and the response of the pupils, testing for muscular weakness, the diminution or exaggeration of reflexes, particularly tendon reflexes, and for loss of position sense and of cutaneous sensation. It always seemed curious to me that, after a demonstration of changes in higher neurological function, an important determinant of the presence or absence of an upper motor neurone lesion should depend on whether the big toe underwent plantar or dorsi flexion when the lateral aspect of the sole of the foot was scratched with a key! An up-going big toe, a positive plantar response, was indicative of an upper motor neurone (most often cerebral) lesion. As a medical student on my father's "firm" at the London Hospital in 1952 I witnessed at his ward rounds the confirmatory plantar response being elicited by the key to his Rover.

Radiology at that time could detect only very major changes, such as a shift in the position of the radiotranslucent, cerebrospinal fluid filled ventricles. The elegant confirmation of the presence of neuroanatomical lesions and of vascular disorders

\footnotetext{
* Dr Michael C Brain is the late Lord Brain's literary executor. Correspondence to: Dr Michael C Brain, 3215 1st Street SW, Calgary, AB, T2S 1P9, Canada. Fax: (403) 243-1468.

Dr Michael C Brain is very grateful to Lady Soames, and Winston S Churchill, MP, for their approval of the suggestion that this account be published, and for correcting the name of the cat. He would also like to thank Sir Martin Gilbert for his encouragement and suggestions, and especially Dr John H Mather for urging him to complete the task of preparing his father's manuscript for publication, and for much
}

additional information about Sir Winston Churchill's health, and Lord Richardson for permission to quote from his letter regarding the electrocardiogram he had taken.

\footnotetext{
${ }^{1}$ Charles McMoran Wilson, lst Baron Moran (1882-1977), was President of the Royal College of Physicians from 1941 to 1950 and physician to Winston S Churchill from 1940 to 1965 . He was the author of Anatomy of Courage, London, Constable, 1945, and Winston Churchill: the struggle for survival 1940-1965. Taken from the Diaries of Lord Moran, London, Constable, 1966.
} 
came decades later with computerized tomography scans, the magnetic resonance imaging, ultrasound, and the electro-physiological techniques. The correct diagnosis of diseases of the nervous system was, at that time, the acme of the hallowed tradition of making diagnoses based on the patient's symptoms and the interpretation of the physical signs. This dependence on clinical expertise in making a diagnosis had been supplemented and to some extent superseded in other disciplines of clinical medicine by the electrocardiogram, and by biochemical, physiological and radiological investigation and assessment of organ function.

W Russell Brain was elected President of the Royal College of Physicians in June 1950, succeeding Lord Moran, a position to which he was re-elected until 1957 when he declined to serve longer. His successor, Sir Robert (later Lord) Pratt said of him:

To some of us Russell Brain before 1950 was the writer of a textbook (a very good one), we had not seen him as a leader of the profession; but fortunately for the College there was a substantial body of Fellows who knew better, and some more who were easily persuaded, so he was elected to the presidency without serious opposition. To those who had previously been ignorant, he at once showed his true qualities. Amongst these I would put very high his amazing (intuitive it almost seemed) grasp of a situation and of the possible consequences of action, and his calm and outwardly unruffled self-confidence which carried such conviction without any show of omnipotence, that you were persuaded that he knew best, not bullied into reluctant acquiescence. ${ }^{2}$

By the end of his presidency Brain was one of the most widely known and respected members of his profession. He served on two Royal Commissions, and chaired a number of important committees. He was editor of Brain from 1954 until his death in December 1966. He was President of the British Association for the Advancement of Science for 1963-64, an honour to a physician or surgeon in active practice last conferred on Lord Lister. He was elected FRS in 1964, knighted in 1952, became a baronet in 1954, and was created a baron in 1962. Pickering has described him as "physician, medical statesman, essayist, public servant, medical scientist, and poet". 3

As a person he was something of an enigma to many. He appreciated solitude and silence, his lack of small talk was disconcerting, and his silences could be disturbing. Yet, his well prepared and self-rehearsed public speeches, addresses and orations were disarmingly spontaneous, erudite and witty. He read rapidly and widely, piles of books being brought home from the London Library each week. He kept a series of notebooks, ${ }^{4}$ the current one was always at his bedside so that he could record the impressions and conversations of the day, quotations from the books he was reading, and the ideas that came to him during the night. The notebooks were the source of his essays, and provided the record of conversations he had with Walter De La Mare, which was published as Tea with Walter De La Mare in $1957 .{ }^{5}$ The notebooks contained some of the material for this essay. It would

\footnotetext{
${ }^{2}$ G W Pickering, 'Walter Russell Brain, First Baron Brain of Eynsham 1985-1966', Biographical Memoirs of Fellows of the Royal Society, 1968, 14: 61-82, on p. 73.

${ }^{3}$ Ibid., p. 73.
}

\footnotetext{
${ }^{4}$ Now preserved in the library of the Royal College of Physicians of London.

${ }^{5}$ Russell Brain, Tea with Walter De La Mare, London, Faber and Faber, 1957.
} 


\section{Encounters with Winston Churchill}

seem that 'Encounters with Winston Churchill' was first dictated, as was his practice, possibly months or years, before Churchill's final illness, and completed shortly after his death. It was read to the $63 \mathrm{Club}$, of which I was a member, in the winter of 1965-66. The Club had its origins in the Essay Society at New College, Oxford, and it met one Sunday evening a month during the winter at a club in St James's Street.

Brain was a conscientious objector in the First World War and served as a radiological technician with the Friends Ambulance Unit, where he met his future wife. He subsequently became a member, with his family, of the Religious Society of Friends. Although understandably pre-occupied with his career and therefore often absent from home, his abilities as an imaginative story-teller, skill as a conjurer and as an operator of a Punch and Judy Show with all the puppets, together with the weekly letters he wrote to each of his three children when they were away from home, established a bond for which they were all grateful.

The publication in May 1966 of Lord Moran's book Winston Churchill: the struggle for survival, 1940-1965. Taken from the diaries of Lord Moran ${ }^{6}$ was followed by criticism of the author in reviews, editorials and letters to the editors in the British press because he had failed to obtain the permission of the Churchill family to publish his account of Churchill's illnesses. ${ }^{7}$ Nor had he obtained the permission of others he quoted in his book. The British Medical Association and members of the medical profession in general thought the publication contravened the requirement to maintain the confidentiality of information obtained as part of the doctor/patient relationship.

Lord Brain, as he then was, received a pre-publication copy of the book inscribed "Russell from Charles, April 29 1966". He was upset that he had been quoted without his knowledge and permission, and was offended by the two comments made about his seeming failure to communicate adequately with Winston Churchill.

Brain is not good at patter. He did not seem to discern that the P.M. was seeking reassurance. ${ }^{8}$

Russell listened attentively to Winston's story, but offered no comment. Winston waited impatiently for suggestions, but they did not come. He had told Brain the whole story that he might get his help. He wanted to be told that his mind was not giving way. He wanted to do something. "No," Brain said shortly, "there is nothing I can add to the treatment." Brain is an honest man, he has no patter. ${ }^{9}$

These observations were disturbing, as Brain thought that if the book was widely read they might be detrimental to his clinical practice. Legal advice was sought, but wisely the issue was not pursued. Although the remarks about the lack of patter ring true, their publication showed a gratuitous insensitivity to the feelings of a loyal and very supportive colleague. On 9 May 1966 Brain wrote a letter to The Times which was published the following day. After acknowledging that Lord Moran had sent him a copy of the book, he went on to say:

\footnotetext{
${ }^{6}$ Moran, Winston Churchill, op. cit., note 1 above.

${ }^{7}$ Richard Lovell, Churchill's doctor: $a$ biography of Lord Moran, London, Royal Society of Medicine, 1992, ch. 23, 'The great book row', pp. 377-95; and Winston S Churchill, His father's
}

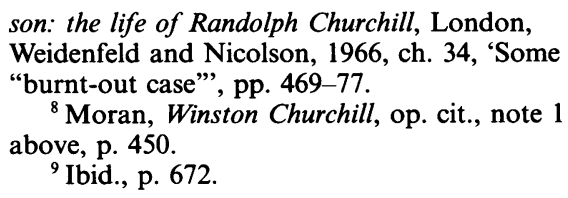
Weidenfeld and Nicolson, 1966, ch. 34, 'Some "burnt-out case", pp. 469-77.

${ }^{8}$ Moran, Winston Churchill, op. cit., note 1 above, p. 450.

${ }^{9}$ Ibid., p. 672. 


\section{W Russell Brain}

Since Lord Moran has already alluded to me in one of the published extracts, I must point out that these confidential matters have been published without my knowledge.

To put matters in perspective, my notes show that I was first asked by Lord Moran to see Sir Winston in October, 1949, and that I saw him on 20 occasions, the last being during his final illness. Sometimes for various reasons I saw him alone, once, at least, at his request.

During these 15 years I came to know him well, and I cannot accept the accuracy of all that Lord Moran says about the consultations which he reports.

Having said that, may I say one thing more? I hope that this unhappy controversy will not be allowed to obscure Lord Moran's great services to Sir Winston. Over the years I saw his devotion at first hand, and I know that it was given at great personal sacrifice. In addition Lord Moran has done much for medicine in this country.

Ethical considerations are rightly emphasized and errors of fact must be corrected, but I hope that Lord Moran's medical critics in particular will now feel that, their protest having been made, the matter should be allowed to rest. ${ }^{10}$

One of the "errors" that "must be corrected" mentioned in the last paragraph was in all probability an allusion to the fact that whereas Brain, according to his notes, first saw Sir Winston in consultation at Moran's request on 5 October 1949, Lord Moran's book states that this first consultation took place some seven months later on 25 May 1950. It is difficult to account for a discrepancy of this magnitude if the book was, as the title page claims, "Taken from the diaries of Lord Moran" (the emphasis was in the original). Statements made in the Preface make reference to a diary:

... it became my custom ... to note, sometimes on the back of an envelope, anything that he said that which might help me to get to the bottom of his troubles. From these notes I wrote out the conversations with Winston the same night. They are printed as they were recorded at the time. I have not touched them since.

I had at that time no thought of writing for publication, and the diary in its original form contained much that could not be properly published for many years. I think it was Brendan Bracken who first pressed me to turn my diary into a book. ${ }^{.1}$

The format of the book also suggests that it was based on a diary as the passages are usually preceded by the month, day and year. However, Richard Lovell in the Preface to his biography of Lord Moran describes the family papers associated with his Churchill years as follows:

In his Churchill years, the earliest ordering of his thoughts from his jottings (some of which, often barely legible, were also scattered through the family papers) appeared in diary form in closely written loose-leaf manuscript books, which overflowed into collections of separate pages. Judging by the varied use of past, present and future tenses, and reference under some dates to events that had not yet happened, these manuscript books cannot be regarded literally as a diary. ${ }^{12}$

Since Russell Brain did record in his account a follow-up visit to Winston Churchill

\footnotetext{
${ }^{10}$ Lord Brain, The Times, 10 May 1966, Letters to the Editor.
}

\author{
${ }^{11}$ Moran, Winston Churchill, op. cit., note 1 \\ above, pp. xv-xvi. \\ ${ }^{12}$ Lovell, op. cit., note 7 above, p. xiii.
}




\section{Encounters with Winston Churchill}

on 25 May 1950, the date on which Lord Moran implied the first consultation by Brain took place, it seems likely that Moran had either failed to record the earlier consultation on 5 October 1949, or the record of it, if there was one, was mislaid, hence the error. The problem may have been compounded by the lack of typewritten record of consultations. Since Lord Moran was usually present at my father's consultations there may have been no perceived need for a formal note of the consultation.

As my father's literary executor I have for a number of years considered the appropriateness of publishing my father's account of his encounters with Winston Churchill. I am grateful to Sir Martin Gilbert who encouraged me to do so, and to members of the Churchill family for granting their permission.

\section{Encounters with Winston Churchill W Russell Brain}

I think I should put on record my encounters with Winston Churchill ${ }^{13}$ for several reasons. I saw him as a patient on a number of occasions beginning in 1949, and I looked after him during his serious illness in 1953, when he was Prime Minister. Anthony Eden also was seriously ill at the time, ${ }^{14}$ and if Churchill had had to resign the Premiership on grounds of ill-health, the Queen would probably have had to send for Butler, ${ }^{15}$ and subsequent English political history at least would have been different. These facts alone seem to justify my putting on record what happened. Apart from that, Churchill is part of history, and almost anything he said and did may have a special interest. I have for a long time made it a practice to write down what I could remember afterwards of the conversation of people whose conversation seemed to be worth recording, and I did that with Churchill. Since my notes are entered in my notebooks and his medical records are on the type of folder I use for patients, since the latter may not always be completely legible, it seems to me to be a good plan to bring the two together in chronological order. ${ }^{16}$ Moran originally called me in to see Churchill. He was present on most of the occasions when I saw him, but for various reasons, I sometimes saw Churchill alone. Moreover, Moran, I'm sure, has no detailed record of the results of my medical examinations. ${ }^{17}$

What ought to be done with this record when it is completed? It is a sound principle that doctors should maintain secrecy about their patient's illnesses, and

\footnotetext{
${ }^{13}$ Sir Winston Spencer Churchill (1874-1965).

${ }^{14}$ Sir (Robert) Anthony Eden, later lst Earl of Avon (1897-1977), Foreign Secretary 1951-1955, Prime Minister 1955-1957. In spring 1953, Eden had two unsuccessful operations for obstructed bile ducts. A third successful operation was performed in June at Harvard Medical School, Boston, USA, and after an extended convalescence he returned to his Foreign Office duties in October.

${ }^{15}$ R A Butler, later Baron Butler of Saffron Walden (1902-1982), Chancellor of the Exchequer in 1953.
}

\footnotetext{
${ }^{16}$ See note 4 above.

${ }^{17}$ The visits of Sir Russell Brain to Winston Churchill on 5 and 15 October, and 8 December 1949 are not mentioned in Moran's Winston Churchill, which records his first consultation as taking place on 25 May 1950. The lack of mention of eight of the subsequent visits was probably due to either independent follow up consultations by Brain alone, or Moran's inability to be present because of other commitments.
} 


\section{W Russell Brain}

with that object in view, their medical records should be destroyed. However, I doubt if there are any absolute ethical rules and sometimes there is a conflict of obligations. The main thing is to see that no avoidable harm is done, and that there may well come a time after Churchill himself is dead, when publication of this account of his health may do no harm to anyone and actually be of some historical importance.

\section{The First Consultation}

October 5th $1949:{ }^{18}$ On this day I saw Churchill for the first time as a patient at Chartwell. ${ }^{19} \mathrm{He}$ was in a bed between single and double in size, the right side against the wall, which carried a shelf full of proofs, which he was correcting. On his left was a double decker locker of the hospital type, upon which, amongst other things stood a whisky and soda, while on the floor nearby was a white enamel bucket into which he shook his cigar ash. He was wearing a dark red and gold bed jacket and a kind of abbreviated night shirt which reached just below his waist, and had a division down the middle behind because, he explained to me, he wrote a good deal in bed. When Moran and I went into the room, he handed his partially smoked cigar to his valet.

Before we saw him, Moran had told me that some years previously while in the U.S.A., he had had an attack of vertigo and unsteadiness, the latter taking some weeks to settle down, and attributed to a labyrinthine lesion. Also in the U.S.A., just after Pearl Harbour [sic], he got up in the night to open a window and got pain in the chest. Moran feared he had had a coronary thrombosis but owing to the circumstances, could not get an electrocardiogram done, and Churchill carried on as usual, though complaining of dyspnoea. ${ }^{20}$ On return, he saw Parkinson, ${ }^{21}$ who did an electrocardiogram, and refused to commit himself. In the summer of 1949 before he went abroad, he asked Moran to feel his pulse after bathing, and Moran thought it poor volume. Moran said he smoked thirteen cigars a day and took a

\footnotetext{
${ }^{18}$ On this day, Churchill was eight weeks (less a day) before his seventy-fifth birthday. He was the member of Parliament for Woodford, Chairman of the Conservative Party, and leader of the opposition in the House of Commons. Churchill's engagement cards in the Churchill Archives, Churchill College, Cambridge, record Brain's visits to Churchill on 15 October and 8 December 1949. The card for 5 October records that Lord Moran and a "Dr Grey" had an appointment at 7.15 p.m. (personal communication from Dr John Mather). It seems probable that the "Dr Grey" referred to was a mistaken transcription of a telephone message from Moran telling Churchill that he was bringing a "Dr Brain" to see him.
}

\footnotetext{
${ }^{19}$ Chartwell was Churchill's country home in Kent.

${ }^{20}$ Moran, Winston Churchill, op. cit., note 1 above, pp. 17-18. Instead of a "coronary" event which appears not to have been confirmed by the electrocardiogram performed by Sir John Parkinson, an alternative explanation is that he strained a muscle of and/or the bony and cartilaginous chest wall that contributed to a Tietze Syndrome. See John Mather, 'Sir Winston Churchill: a study in pathography', chapter in Churchill: the postwar years, forthcoming.

${ }^{21}$ Sir John Parkinson (1885-1976), consultant cardiologist.
} 


\section{Encounters with Winston Churchill}

fair amount of alcohol-three brandies after dinner-but was never the worse for it. $^{22}$

Churchill began by saying: "You reconnoitre first, and then we'll have the history of the campaign", by which he meant that he wanted me to examine him before he gave me his history. However, this was bad medicine, so I explained to him that we must have the history first. He said: "On August 28th I had been bathing and painting during the day, and I was sitting up at 2 a.m. playing gin rummy and suddenly I felt my right leg go numb. It felt numb to above the hip, and also in the region of the shoulder, and when I tried to write down the score, I could not write properly. The next morning my leg was still numb and I sent for the local doctor, a Scotsman. ${ }^{23}$ Moran arrived at 11 a.m. They thought my speech was a little affected. It was very slight, as if I was between asleep and awake." He said there was a sensation like lumps in the upper part of the right thigh, but nothing to be seen. Writing difficulty, which was motor, lasted three days. There was slight difficulty in walking. He was still unsteady on reaching England in the plane from La Capponcina in the south of France, ${ }^{24}$ but not now. He still got an occasional tight feeling in the right leg, right shoulder and the right side of the back near the spine. There was a pleasant warm feeling in the region of the old appendectomy and herniotomy scars. "Occasionally I get the twitters"-a momentary feeling of giddiness. Also as if outside of himself, "My body's there and I am here" with his hands six inches apart.

Examination revealed the following. Speech and articulation were normal. The optic discs were normal, but there was some retinal arteriosclerosis. Pupils and ocular movements were normal, and visual fields full. The remaining cranial nerves were normal. There was no weakness or ataxia of the limbs; the tendon reflexes were present and equal but the ankle jerks were a bit sluggish. The plantar reflexes were right; extensor, left; flexor. The abdominal reflexes were absent. There was no cutaneous anaesthesia. Pin prick was felt slightly less acutely on the right forearm than on the left. There was no postural loss. Vibration felt less acute on the right shin than on the left. Romberg's sign was negative and the gait normal. There were frequent extrasystoles and the blood pressure was $160 / 90$. There was nothing abnormal to be found in the abdomen except appendicectomy and herniotomy scars.

After it was explained to him that his symptoms were due to a temporary impairment of the circulation through a part of his brain, ${ }^{25}$ he started to talk about the current political situation, and his reaction to it. "And then there was this

\footnotetext{
${ }^{22}$ Moran, Winston Churchill, op. cit., note 1 above, p. 333. Now seventy-five, Churchill had evidence of arteriosclerosis: "When I examined Winston's retinal arteries with my ophthalmoscope, I found definite hardening of the vessels, but not more than would expect after the stress of the war years. There is plenty of evidence that his circulation is sluggish."

${ }^{23}$ Dr John Roberts, the family physician in Monaco.

${ }^{24} \mathrm{La}$ Capponcina was the residence of Lord Beaverbrook on the French Riviera where Churchill had his first major stroke. See Michael
}

\author{
Wardell, 'Churchill's dagger: a memoir of La \\ Capponcina', Finest Hour, 1995, 87: 14-23. \\ ${ }^{25}$ Moran, Winston Churchill, op. cit., note 1 \\ above, p. 334. Churchill was always very \\ interested in his health but Moran began a course \\ of down-playing the significance of this and \\ subsequent strokes. He responded to Churchill's \\ inquiry, "Most people when they speak of a \\ stroke mean that an artery has burst and there \\ has been a hemorrhage into the brain. You've not \\ had that. A very small clot has blocked a very \\ small artery."
}




\section{W Russell Brain}

devaluation. You may have read about it. We have had a stroke! I have no ambitions. I have my life. But I have my duty. I am Leader of the Conservative Party. We don't know when this Election will come. They will keep us guessing. I may be worth a million votes to the party. I must warn you that whatever advice you give me, I mean to go on. I am not afraid to die." (He had previously said to Moran: "It looks as though it were a choice between death and the Treasury Bench.") Moran had told him not to have his bath water too hot, and he asked me about this. "I have two baths a day. I enjoy my baths; they mean as much to me as my meals." He was due to have one and it was supposed to be ready for him, he insisted on our going to feel the water, which, however, he had to admit, was not as hot as usual. By this time he was wandering around in his ridiculous little bed jacket and night shirt, bare from the middle thighs downwards. "You must see me walk" he said, and did a kind of goose-step, and then stood still with his eyes closed to show how steady he was. He insisted on our having a drink, though Moran was anxious to get away as the Duke and Duchess of Westminster were coming to dinner, and it was essential for political reasons that no one should know that I had seen Churchill. However, he got his way. "I diagnose that you would like some sherry!" We drank a hasty glass and left him splashing in his bath. The Duke and Duchess of Westminster arrived, and Moran and I had to hide in the Secretary's room. Mrs Churchill was in London, so they probably had to wait half an hour for Winston, which Moran said was not unusual.

Moran said driving home that Churchill owed all his success to his power of words, which had given him his control over the House of Commons. He would not agree that he was a military genius, and he thought that left only his painting. I think there is a good deal in this, in that Churchill, without his oratory, would have been a very much smaller man, but my impression is that his genius lies chiefly in his imagination, linked with his power of expression-and it is a nice point how far they can be separated. He is an intensely sensitive and imaginative man, but this is balanced by his will-power. He justifies what I said in my Dalton lecture about the genius of the man of action. ${ }^{26}$ His will-power directs his imagination on to events and also controls it. The artist may have equal imagination but his will-power is devoted to it for its own sake, or like Coleridge's may fail altogether. ${ }^{27}$

I should think that from what Moran told me that Churchill is a cyclothyme. Apparently he was subject to depression in his earlier days. ${ }^{28} \mathrm{He}$ has the drive and vitality and youthfulness of a cyclothyme. He works five or six hours a day at his

\footnotetext{
26 'Some reflections on genius', published in the Eugenics Review, 1948-49, 40: 12-20, and in Some reflections on genius and other essays, London, Pitman Medical Publishing, 1960.

${ }^{27}$ Churchill and the relationship between imagination and will-power in "the man of action" are analysed extensively by Anthony Storr in several of his writings. See, for example, 'The man', in Churchill revised: a critical assessment, ed. A J P Taylor, New York, Dial Press, 1969.
} 


\section{Encounters with Winston Churchill}

book. ${ }^{29} \mathrm{He}$ looks a little more than sixty at seventy-four. His grip is strong. To demonstrate something he made me sit on his bed while he pressed on my back. It was like the hug of a bear!

He has six secretaries and a university don and a lawyer and a high ranking officer of the Army, Navy and R.A.F. to help him in the preparation of his book. He explained that he had finished the third volume but was now putting it into shape. "They are now trying to tone down what I had said about General Auchinleck-that bloody man-I could not get him to fight." 30

October 15th, 1949: I saw him again, and there was no substantial change in his condition. Speaking of the political situation he said: "Give us some encouragement, they say, but you mustn't be violent. Tell us your plans, but don't commit yourself. It isn't easy to do all these things with aplomb." When I told him that the postponement of the election would give him four months respite--"Yes, but in four months time, I shall be four months older. That I think is incontestable."

December 8th 1949: I saw him again at Hyde Park Gate. ${ }^{31}$ He was in bed with his usual cigar and whisky and soda. Later he got out of bed and wandered around in his little vest. He described his symptoms as follows: "It is a quiet and agreeable, warm, india-rubbery, velvet feeling in the right groin and a stiffness around the shoulder. The first sensation was a lump which did not exist. There is no pain and no disability. It is like a sheet of warm material one-sixteenth of an inch thick and one inch from the surface, spread out over it." Pointing to a sorbo pad, he said: "It feels like this, but only half as thick and frayed at the edges." He had no subjective anaesthesia and there had been no difficulty in writing. He had been painting during the last few days.

Examination revealed no loss of light touch, pin prick, or appreciation of passive movement. The knee and ankle jerks were sluggish but equal, and the plantar reflexes flexor.

Talking afterwards, he said he thought the election would come in February. If Labour got in with a majority of fifty or sixty, he would retire from active politics and remain in the House of Commons. If the Conservatives got in, he presumed he would take office. He didn't think this would mean more work than he did now. He had always worked hard. Instead of sorting telegrams (for his book) there would be the boxes and the shorthand writer to take down his comments. He only wanted to get back because he couldn't bear to see everything so mis-managed. Labour would end the Cabinet system: it was the last chance of "the Western System". What we had now was "government for the underdog by the underdog: government of the half-wit, by the half-wit, for the half-wit." He had been making political speeches and added: "The speeches, they say, have been (pause) up to the level!"

May 25th, 1950: I saw him again. His symptoms were unchanged, and there were no abnormal physical signs. I have no further record of this meeting.

\footnotetext{
${ }^{29}$ Churchill's memoirs were published as The Second World War, 6 vols, London, Cassell, 1948-1954. During this seven-year span Churchill had two major strokes in 1949 and 1953, and several episodes of cerebrovascular insufficiency
}

characterized by complaints of dizziness, lightheadedness and numbness of the face.

${ }^{30}$ General Sir Claude Auchinleck (1884-1981).

${ }^{31}$ Churchill's London home. 


\section{W Russell Brain}

\section{The Major Stroke}

June 24th, $1953:{ }^{32}$ I had a mysterious message from Moran asking me to go and see Churchill with him at 10, Downing Street. He did not give any reason for this, and at the time, I was involved as Chairman of the Joint Consultants' Committee in negotiations with the Government about doctors' pay, which I had discussed on more than one occasion with Moran, who, of course had direct access to Churchill. I thought at first that he had found an opportunity to discuss this with the Prime Minister but when I got there, I found that Churchill had had a stroke.

He had been feeling very tired lately on account of the Coronation and of having to do the work of the Foreign Secretary as well as his own on account of Eden's illness. The previous morning Moran had been to see him to pay a routine visit and thought his speech was somewhat slurred. In the evening, he had presided over a dinner for the Italian Premier, at the end of which he had made a speech, and again his speech was somewhat slurred, and he became unsteady on his legs, and had to be assisted out of the room. He had a good night and on the morning of June 24th, Moran saw him again, and found his speech still slurred. He presided over a Cabinet Meeting, however, which lasted two hours. He felt very tired, and his slurring speech was noticed by his colleagues. He slept in the afternoon and his secretary mentioned that she thought there was some drooping of the left side of his face.

This was apparent when he spoke and also when he smiled, and his speech was at first somewhat slurred, but there was at no time any evidence of aphasia. There was slight weakness of the left lower face on voluntary and emotional movement, and his tongue deviated slightly to the left. There was no weakness of the limbs, and no change in sensation, but the left plantar reflex was extensor while the right was flexor. He walked about the room with only a slight trace of unsteadiness. He said he had no headache but felt as though there was something in his head. He was put on a dose of trinitrin night and morning.

After my examination was finished, Churchill gave me an address on foreign policy. Since he had taken Eden's place as Foreign Secretary, he said, our influence in the world had increased. He didn't always agree with Eden but nine times out of ten, he did, but he had been firmer with Neguib, and Neguib saw we meant business. ${ }^{33}$ It should be possible to settle Egypt soon, but we couldn't afford to keep 80,000 men there. Egypt wasn't worth it: its strategic importance was much less. Then Korea-a terrible business. All was going well. "I had stretched out a paw-privately to the Russians, and suggested that the time had come to lay off at Panmunjon, and the Americans were being brought along, and then that bastard, Syngman Rhee, deliberately and maliciously wrecked it all. ${ }^{34}$ Now it is all very difficult. We could withdraw, under sufficient rearguard cover, but South Korea would be overrun and we would lose all that 150,000 American lives and perhaps 5,000 British had been

\footnotetext{
${ }^{32}$ Churchill had been Prime Minister since 26 October 1951 following the Conservative Party victory at the General Election.
} 


\section{Encounters with Winston Churchill}

sacrificed for. It is very difficult, but we must send reinforcements. A brigade is going from Hong Kong. People would be surprised who thought all we wanted was to get out."

At the time the Bermuda Conference was pending and if Churchill couldn't go, Eden being ill, there was no one to take his place. Churchill discussed the problem of Eden and said that if he gave up the Foreign Office and put someone else in, there would be no post for Eden to go to when he got back. It was clear that if Churchill had to resign owing to illness, Butler would become Prime Minister. ${ }^{35}$

June 26th, 1953: I went down with Moran to see him at Chartwell. He had been moved there because it was felt that he would be more out of the limelight. He had obviously deteriorated. His speech was more dysarthric and his left hand was becoming weaker and his gait more unsteady. At times he would choke and cough when swallowing. There was considerable clumsiness of the left hand, but his left grip was still fair and movements of the arm at the elbow and shoulder good. The main weakness was in the small muscles of the hand. Power was little diminished in the left lower limb, but he tended to stagger to the left when he walked. There was no impairment of appreciation of pin prick or postural sensibility. The tendon reflexes were brisker on the left side than on the right, and as before, the left plantar was extensor while the right was flexor.

June 28th, 1953: Seen again at Chartwell. No substantial change.

July 3rd: Seen again at Chartwell. The previous night he had had an attack of jerking of the left leg involving flexors of all joints and slight jerking of the left hand. This went on for a quarter of an hour or more. Since I last saw him, he had become still weaker in the arm and leg, and was unable to walk, but now he was improving and his speech was better.

There was still weakness of the left lower face and left half of the soft palate, but his tongue deviated slightly to the right. The left grip was fair and there was moderate weakness of all movements of the left upper limb. There was general weakness also of the left lower limb in which plantar flexion was fair and the power of dorsiflexion and inversion of the foot was just returning. As before, the tendon reflexes were

\footnotetext{
${ }^{35}$ The political crisis created by Churchill's stroke and how it was handled are described by Sir John Colville (1915-1987), his private secretary, in The fringes of power: Downing Street diaries 1939-1955, London, Hodder and Stoughton, 1985, p. 668. "Two days after his stroke, when I drove down to Chartwell alone ... (Lady Churchill having gone ahead to prepare the household), he gave me strict orders not to let it be known that he was temporarily incapacitated and to ensure that the administration continued to function as if he were in full control." "It looked as if he would have to resign and I was in constant touch with Tommy Lascelles [the Queen's private secretary], Lord Salisbury, Eden and Rab Butler. A Caretaker Government under Lord Salisbury for six months, until the Conservative Party could
}

choose between Eden (now convalescing in America from a gall-bladder operation) and Butler, was mooted. But W.'s recuperative powers, both physical and mental, invariably outstrip all expectation and after a week he began rapidly to improve, though his powers of concentration appeared slight and he preferred Trollope's political novels to work." (Copyright 1985 Hodder and Stoughton. Reproduced by permission of Hodder and Stoughton.) Colville goes on to describe in detail how the Fleet Street press was gagged, and that not a word of the Prime Minister's stroke was published until Churchill casually mentioned it in a speech to the House of Commons a year later. He also describes how decisions were taken despite the incapacity of the Prime Minister. 


\section{W Russell Brain}

brisker on the left side than on the right, and the plantars were left extensor, right flexor, and there was no sensory loss. He was now able to use his left hand to propel his wheel chair, and to walk unaided a few steps. I noted that the right carotid pulse was still much smaller in volume than the left.

July 25th: This was the next time I saw him, and he was now at Chequers, ${ }^{36}$ much improved, and his speech more normal. The was no dysphagia now. He had a little weakness of the left lower face. In the upper limb, there was now little weakness at any joint. He could brush his hair and move his fingers individually. In the lower limb, all movements were good against resistance. He walked with a slight limp. He could do a "knees-bend" twice and had climbed on to a chair and stood on it. $\mathrm{He}$ walked well and quickly, but with slight ataxia of the right lower limb at the ankle. The reflexes were as before. There was no sensory loss but subjectively he complained of two numb areas on the outer side of the left lower limb above and below the knee. He said the right side of the body (which had previously been affected) felt more abnormal than the left.

His blood pressure was 170/90. There were occasional extrasystoles but his pulse did not become rapid even after considerable exertion. He still had some frequency of micturition and some precipitancy.

He has noticed loss of emotional control. He said that he was "always rather blubbery" but now he was much worse. He wept if moved, for example, by poetry. He read me from The Times a passage saying that more attention had been paid to him in the Russian press than to Stalin, and this made him weep. I had a vivid memory of him getting out of bed in his little night shirt and striding up and down the room with his hemiplegic left arm and leg to show me what he could do, and he took me along to his tank of fish. In conversation he said that if the tension between Russia and the Western Powers could be relaxed, by giving Russia guarantees against aggression, the production of the world could be doubled within a few years, and people could have what they needed more than anything else-leisure (he said this very emphatically). They could work hard for four days and have the other three to enjoy themselves.

August 12th: I saw him today with Moran at 10, Downing Street, being convalescent, he was in the Cabinet Room sitting in the Prime Minister's chair with the usual extinct cigar and a whisky and soda. "Pray take your seats at the Cabinet Table", he said.

We walked in the garden and then went up to his bedroom in the lift. It was very hot, and he lay on his bed in his vest and called for an electric fan. He now has ninety percent recovery of power in the left face and upper and lower limbs, when examined in bed, but he does not swing his arm in walking and tends to catch his toe. His left plantar reflex is still extensor. He still gets occasional twitching of his left leg. His emotionalism is very much less. He is generally stronger. "I've got more bite", he said, clenching his teeth. He appears to notice his old uncomfortable

\footnotetext{
${ }^{36}$ Chequers: the Prime Minister's official country residence.
} 


\section{Encounters with Winston Churchill}

sensations in the right side of his body more than he did before he had his fresh lesion.

August 25th: I saw him again at 10, Downing Street. He took Cabinet last week and was very tired afterwards, and both legs twitched for an hour and kept him awake. He complains that his walking varies and he seems loose at the knees. He was walking badly yesterday but not much wrong today. There was no change in his physical signs. I think the trouble is variability in the collateral circulation, influencing the highest levels of control.

He saw Parkinson yesterday who finds his heart satisfactory. His pulse today was 84 after exercise, falling in half a minute to 76.

June 22nd, 1955: ${ }^{37}$ Two weeks ago while dining at Chartwell, on getting up he felt as if drunk - swimmy. After this, he had difficulty in controlling his right hand, misjudged distances, and knocked things over. His writing got very bad and he became a bit unsteady on his feet. Moran stayed with him for five days and he has steadily improved. Moran said that his speech became worse at the time.

$\mathrm{He}$ is still somewhat dysarthric, his speech not always intelligible. Otherwise there was no change in his physical signs except that now both plantars were extensor. There was no ataxia, nystagmus or new sensory loss. His gait was fairly good with an effort. He was said to be good in the mornings and unresponsive at lunch-time unless he took benzedrine.

November 1st, 1956: Seen with Lord Moran. Twelve days ago while in the South of France, he got up to go to the lavatory, found his right leg was weak and fell down, and does not remember anything more for twenty minutes. He thinks he was alright after this, but Dr. Roberts, ${ }^{38}$ who saw him, reports that he had loss of speech, and weakness of the right arm and leg. He also mentions weakness of the left face, but that is probably a relic of the previous attacks. He complains of no symptoms now. I thought he was slightly dysarthric, but there was no weakness of the face or tongue or limbs. Both plantars were extensor. It was difficult to feel any carotid pulse on either side of the neck.

October 15th, 1959: Seen with Lord Moran. The previous day he had a sudden attack of speech difficulty. He could say very little for an hour or two, then there was rapid improvement. Now he made only occasional mistakes with words, and slight slurring. About the same time, his right little finger felt dead and became cold. ${ }^{39} \mathrm{He}$ has slight expressive dysphasia, otherwise there was no change in his neurological condition. His right little finger was cold and blanched. There had clearly been two small emboli, presumably from an atheromatous plaque in the aorta. He was due to speak the next day in his constituency which was very important because his adoption as a candidate might depend upon it. He insisted on going and got through it.

\footnotetext{
${ }^{37}$ Churchill resigned the premiership on 5 April 1955.

${ }^{38}$ See note 23 above.

${ }^{39}$ Churchill had visited President Eisenhower in the USA in May 1959. He returned with a dry gangene of his right little finger and Moran had
}

\author{
him seen by Professor Charles Rob, vascular \\ surgeon, St Mary's Hospital. See also, John \\ Young, Winston Churchill's last campaign, Oxford, \\ Clarendon Press, 1996, pp. 183-209, and Henry \\ Pelling, Churchill's peacetime ministry, 1951-1955, \\ Basingstoke, Macmillan, 1997, pp. 89-105.
}




\section{W Russell Brain}

October 22nd, 1959: Mr Montague Browne ${ }^{40}$ rang up and said that Churchill had suddenly become unconscious. Moran was in Bath and would I go at once. I got to Hyde Park Gate about twenty minutes later, by which time they had got him upstairs and into bed. Mr Brown said that they had both been sitting in the same room when Sir Winston said he felt ill. He looked very pale and his eyes turned up. He was unconscious. There was no convulsion.

Churchill was in bed looking rather pale. His pulse and respirations were normal. He could be roused to speak and at my request, moved both arms and legs and grasped my hands. There was no paralysis and I concluded that he had had a minor epileptic attack. I stayed for an hour or more and had tea with Lady Churchill, who said that they had lunched at the Savoy with Randolph and Sir Winston had seemed normal then but perhaps a little silent. He was more conscious when I left but drowsy. No paralysis had developed and the plantar reflexes were both flexor. I rang up later to find that he was sitting up having some dinner.

October 23rd, 1959: I saw him at 9.15 a.m. with Moran. He said that he had had a good night, and felt quite normal. He was sorry to have caused so much trouble. He did not remember much about the attack, but said it felt as if he were being turned upside down. He seemed as usual. He is to take $3 / 4 \mathrm{gr}$. of sodium phenytoin each morning.

November 17th, 1959: Moran telephoned me in the afternoon and asked me to come at once. I got to Hyde Park Gate in a quarter of a hour. Churchill had come up from Chartwell that morning and went to lunch with Beaverbrook. ${ }^{41}$ When he tried to get out of the car he had to be supported, and he had sat through lunch looking pale and saying little. When I got there he was sitting in the library, drowsy and yawning. He could be made to respond, but his speech was slurred, and he had some expressive aphasia. Adenauer was due at six o'clock. ${ }^{42}$ Moran wanted me to persuade Churchill that he was not fit to see him. This was not difficult, and the Adenauer visit was cancelled. Churchill was got up to bed while Moran and I had tea with Lady Churchill. After that he seemed to be reviving. He said that he would like to play cards. Lady Churchill said she wished he would play something other than six pack Bezique. She added: "Winston is now starting to cheat!"

November 19th, 1959: Moran had gone to Oxford, leaving me in charge. I was rung up at lunch time and went along at three. Churchill had got up as usual, but while waiting for lunch, they found him with several volumes of Edgar Allan Poe and he said he wanted to know what happened to Marie Antoinette. He did not believe she was executed. He slept through most of lunch, and then ate some, but was still preoccupied with the problem. Eventually Lady Churchill got an encyclopaedia to convince him. She was catechised and remembered most of the details. I found him drowsy but recovering. Blood pressure 110/70. He had had a

\footnotetext{
${ }^{40}$ Montague Browne was Churchill's devoted private secretary for many years until Churchill's death.
}

\footnotetext{
${ }^{41}$ (William) Maxwell Aitken, lst Baron Beaverbrook (1870-1964).

${ }^{42}$ Dr Konrad Adenauer (1876-1967), Chancellor of West Germany.
} 


\section{Encounters with Winston Churchill}

bad night with confusion, exhausted by the Adenauer visit which took place yesterday. Bed and then better.

Talking these episodes over with Moran, I suggested that we ought to think of the possibility of a cardiac origin for these episodes, and as a result he asked John Richardson to see Churchill. ${ }^{43}$ I wrote to Richardson on January 28th 1960, giving him an account of what had happened, and ended my letter as follows: "I am sure all of these episodes have been circulatory, and I thought that the cerebral ones were probably due to a fluctuating blood supply through thickened cerebral vessels. It was the attack of syncope which made me suggest to Moran that a cardiac dysrhythmia might be at the bottom of it."

Richardson wrote back on February 1st: "I enclose the electrocardiogram as I think it might interest you with its highly variable pace-maker. I would like to have it back as it is the only one I've got-the other I sent to Moran. I think the finding is important as it would obviously be better for him not to be on digitalis unless the indications are extraordinarily strong."

May 18th, 1961: Some little time previously, Churchill had had a fall in his bedroom which had resulted in a crush fracture of one of his dorsal vertebrae. I was asked to see him again because he was complaining of painful numbness of the left index finger which seemed to have troubled him since his fall. I found some analgesia over the finger. There was no muscular weakness, but the left triceps jerk was diminished. It appeared to be a lesion of the 6th cervical root which I thought was due to cervical spondylosis, exacerbated by the fall. He had had his spine x-rayed and when I saw the X-rays, I found they showed gross changes: marked lordosis from the 1 st to the 5 th cervical vertebrae, while the 5 th, 6 th, and 7 th were kyphotic; their bodies appeared fused together, $\mathrm{C} 5$ and $\mathrm{C} 6$ at an angle leading to the kyphosis, with wide separation of the tips of the spinous processes of these two vertebrae, apparently due to old trauma. This is the cause of the characteristic posture of his head on his shoulders. ${ }^{44}$

June 9th, 1961: I was asked to see him on account of his extreme irritability and outbursts of anger at attendants, etc. I suggested he should be put on Equanil.

\section{The Final Illness}

January 11th, 1965: Charles Moran telephoned to say that Winston was not well and asked me to go and see him. I went between tea and dinner, picking up Moran on the way. As we drove there, he said that Winston was going down hill and the last few days he had been increasingly drowsy. We went straight to his room. His nurse said that he had deteriorated during the last few days. He could no longer stand unsupported. He had recently had difficulty in swallowing solids and fluids,

\footnotetext{
${ }^{43}$ John Richardson, later lst Baron Richardson (b. 1901), consultant physician.

${ }^{44}$ Churchill fractured the head of his right femur in June 1962. X-rays taken by Dr Campbell Golding, diagnostic radiologist, Middlesex Hospital, commented on the same
}

cervical changes. The fracture probably dates from 10 January 1893 when Churchill was unconscious for several days after a severe fall. See Winston Churchill, My early life, London, Thornton Butterworth, 1930, pp. 29-30. 


\section{W Russell Brain}

but was still swallowing semi-solids. He was still moving his limbs on both sides normally.

He lay in bed with both eyes closed, peacefully. One could get a little response to questions - a grunt only, and he would not put out his tongue for me. He was like someone in a deep sleep. I could not detect any evidence of a fresh cerebral lesion, and both his plantars were flexor. I told Charles Moran I thought this was an episode of cerebral ischaemia and it was terminal. We went in to see Lady Churchill in the sitting room. She said he had been deteriorating recently. He could no longer feed himself, which had been embarrassing, and it meant he had had to have meals in his own room. I said he was seriously ill.

I did not see him again but continued to discuss his case with Moran on the telephone. On January 12th I advised nasal feeding and an antibiotic-Acromycin. On January 13th Moran rang up and said that he now had weakness of the left arm and leg. How long would he live-two days? I said it might well be a week. A bulletin might become necessary. January 15th: Moran said Churchill was worse and a bulletin would have to be issued. We agreed on terms.

I had asked Moran on January 11th how much Winston took in about his birthday. Moran said it was hard to know. There had been a musical hall broadcast in the evening and they thought he had appreciated some of it. Lady Churchill said it had been very depressing that he had been so unhappy recently.

Moran kept in touch until Churchill died on January 24th. At one time he had twitching of the legs. I had suggested injections of phenobarbitone for his restlessness and advised this for the twitchings. The weakness of the left arm and leg disappeared after a day or two and was evidently not due to a thrombosis as Moran had thought but to fluctuating circulation. The family rejected nasal feeding so he lived without nourishment for thirteen days after he became unconscious. Moran phoned me on January 22nd and said it was extraordinary that Churchill showed no evidence of dehydration and had passed several ounces of urine though he was not supposed to have had any food or drink for twelve days. Was that possible? I said I thought it extremely unlikely. He said he thought someone might have been giving him fluids. I suggested getting his blood electrolytes done, but this fell through as he deteriorated. Moran said at one time he became pulseless and they prepared for the end but he revived. It was very embarrassing as official plans had been changed, etc. "They must think we are such ninnies!" said Moran. It was alleged that he had spoken to people. Was that possible? I said I thought it very improbable. Moran said that he had thought of publishing a statement about the illness in the B.M.J. and the Lancet as Dawson had done in the case of King George $\mathrm{V}^{45} \mathrm{~A}$ statement had appeared in the Evening Standard's 'Londoner's Diary' which incensed him. He thought that unofficial and inaccurate accounts might be published, but I said it was better to disregard the Evening Standard and do nothing.

\footnotetext{
${ }^{45}$ Bertrand Dawson, later 1st Viscount Dawson of Penn (1864-1945). President of the
} 


\section{Encounters with Winston Churchill}

\section{General Comments}

What has gone before has been a transcription of my notes made at the time. I might add a few general comments. It is indeed a remarkable story, for Churchill's first definite cerebro-vascular lesion occurred in 1949 and in 1964 he was still alive, and fit enough to go to the House of Commons. In 1953, when he was Prime Minister, he had a left hemiplegia - "my stroke"-as he later called it in a speech in the House. This occurred in the latter part of June and in October he spoke at the Annual Conference of the Conservative Party. I well remember watching it on television and wondering what would happen. His stroke had not been made public and I don't think anyone who did not know could have guessed what his condition had been four months previously. All he was left with was a slight limp with the left foot, which he called "a halt in my gallop". When he had been at his worst, I was asked by Christopher Soames, ${ }^{46}$ what I thought the outlook was, and said, while not quite believing it, that I thought that he had a fifty percent chance of recovery. Optimism was never better justified. And when I saw him vigorously stumping up and down at Chequers, I learnt something about what a hemiplegic patient can do for himself.

As a patient, he wanted a reason for everything, but on the whole, when something was explained to him, he was usually prepared to accept it. I remember various things he said, for example: "Alcohol has been a very good friend to me", and "I like to take a fair proportion of my calories in the alcohol." On one occasion at 10, Downing Street, the cat appeared. "That cat", he said, "was here in Chamberlain's day. We call him Munich Bob."47

I have notes about one or two things other people told me about him. Some time about the end of 1955 , Woolton ${ }^{48}$ told me that Churchill had changed in temperament since his illness: he was quite different in Cabinet. "I can't think", he said, "what you doctors have done to him. Before, he used to stick his chin out; now he is genial and humorous, even on serious matters."

MacLeod $^{49}[$ sic] told me on February 3rd 1954 apropos of the formation of the Royal Commission on Mental Health Law, that at a conference with Churchill someone said it was important to have well-known names, to which Winston replied: "Well there's Sir Russell Brain-he's well-known to the public, and there's Mrs Braddock - she's well known to the public..$^{50} \mathrm{My}$ Cabinet colleagues would make a great mistake if they thought that newspaper notoriety was essential to the judgement of eccentricity." MacLeod also said: "The P.M. thinks a lot of you. In the Cabinet when your name came up in connection with the composition of the Royal Commission, he said: 'I have a very high opinion of his grasp of affairs!'”

\footnotetext{
${ }^{46}$ Christopher Soames, MP, later Baron Soames, who was married to Churchill's daughter, Mary.

${ }^{47}$ According to Lady Soames, who was sent a copy of the manuscript of this article by her nephew Winston S Churchill, MP, the name of the cat was "Munich Mouser".
}

\footnotetext{
${ }^{48}$ Frederick James Marquis, first Earl Woolton (1883-1964), Minister of Food, 1940-43, Minister of Reconstruction 1943-45, and Chancellor of the Duchy of Lancaster 1952-55. ${ }^{49}$ Iain Macleod, MP (1913-1970), Minister of Health (1952-1955).

${ }^{50}$ Bessie Braddock (1899-1970), Labour Member of Parliament.
} 


\section{W Russell Brain}

One final clinical memory. I had no doubt at the time that the first two lesions, that is the one which produced the sensory disturbance on the right side, and the second one producing the left hemiplegia, were hemisphere lesions, and that seemed borne out by the diminished carotid pulsations. His attacks of aphasia must also have been hemisphere lesions, but although there was no clear evidence of a brain stem lesion, when I saw the x-rays of his cervical spine, it seemed probable to me that his vertebro-basilar circulation was none too good, and some of the fluctuating cerebral episodes were due to the inadequacy of his vertebro-basilar circulation when his carotid circulation was already impaired. 